\title{
Loss-of-Function Analysis of EphA Receptors in Retinotectal Mapping
}

\author{
David A. Feldheim, ${ }^{1 \star}$ Masaru Nakamoto, ${ }^{1 \star}$ Miriam Osterfield, ${ }^{1}$ Nicholas W. Gale, ${ }^{2}$ Thomas M. DeChiara, ${ }^{2}$ \\ Rajat Rohatgi, ${ }^{1}$ George D. Yancopoulos, ${ }^{2}$ and John G. Flanagan ${ }^{1}$ \\ ${ }^{1}$ Department of Cell Biology and Program in Neuroscience, Harvard Medical School, Boston, Massachusetts 02115, and ${ }^{2}$ Regeneron Pharmaceuticals, Inc., \\ Tarrytown, New York 10591
}

EphA tyrosine kinases are thought to act as topographically specific receptors in the well-characterized projection map from the retina to the tectum. Here, we describe a loss-of-function analysis of EphA receptors in retinotectal mapping. Expressing patches of a cytoplasmically truncated EphA3 receptor in chick retina caused temporal axons to have reduced responsiveness to posterior tectal repellent activity in vitro and to shift more posteriorly within the map in vivo. A gene disruption of mouse EphA5, replacing the intracellular domain with $\beta$-galactosidase, reduced in vitro responsiveness of temporal axons to posterior target membranes. It also caused map abnormalities in vivo, with temporal axons shifted posteriorly and nasal axons anteriorly, but with the entire target still filled by retinal axons. The anterior shift of nasal axons was not accompanied by increased responsiveness to tectal repellent activity, in contrast to the comparable anterior shift in ephrin-A knock-outs, helping to resolve a previous ambiguity in interpreting the ephrin gene knock-outs. The results show the functional requirement for endogenous EphA receptors in retinotectal mapping, show that the receptor intracellular domain is required for a forward signaling response to topographic cues, and provide new evidence for a role of axon competition in topographic mapping.

Key words: Eph; ephrin; retina; axon; topographic; receptor

\section{Introduction}

Most sensory input to the brain is mapped topographically, with nearest neighbor relationships of the projecting neurons maintained in their connections within target areas. In this manner, the spatial information of sensory input can be preserved as it is transferred from one area of the nervous system to another. For example, retinal ganglion cell (RGC) axons project topographically to retinal targets in the brain, allowing visual images to be transferred in a spatially intact form.

In recent years, the molecular mechanisms for topographic mapping have begun to emerge (Drescher et al., 1997; Flanagan and Vanderhaeghen, 1998; O'Leary and Wilkinson, 1999; Wilkinson, 2000). As proposed initially by Sperry (1963), molecules expressed in gradients across the projecting and target fields are believed to give a unique positional identity to each location, with axons mapping to their correct location by matching up these positional values. In the well-characterized visual projection from the retina to the tectum, or to its mammalian equivalent, the superior colliculus (SC), EphA receptors and ephrin-A ligands are expressed in gradients along the anterior-posterior

\footnotetext{
Received Jan. 27, 2003; revised Nov. 24, 2003; accepted Dec. 30, 2003.

${ }^{*}$ D.A.F. and M.N. contributed equally to this work.

Correspondence should be addressed to Dr. John Flanagan at the above address. E-mail: flanagan@hms.harvard.edu.

David A. Feldheim's present address: Department of Molecular, Cellular, and Developmental Biology, University of California at Santa Cruz, Santa Cruz, CA 95064

Masaru Nakamoto's present address: Department of Neurosciences, Lerner Research Institute, The Cleveland Clinic Foundation, Cleveland, $0 \mathrm{H} 44195$.

DOI:10.1523/JNEUROSCI.0239-03.2004

Copyright $\odot 2004$ Society for Neuroscience $\quad$ 0270-6474/04/242542-09\$15.00/0
}

(A-P) axis of both the retina and the tectum. In the RGC layer of the retina, EphA5 and EphA6 (mouse) or EphA3 (chick) are expressed in a temporal $>$ nasal gradient, whereas ephrin-A2, ephrin-A5, and ephrin-A6 are expressed in the opposite, nasal>temporal gradient (Cheng et al., 1995; Feldheim et al., 1998, 2000; Hornberger et al., 1999; Menzel et al., 2001). In the SC/tectum, ephrin-A2 and ephrin-A5 are expressed in posterior $>$ anterior gradients (Cheng et al., 1995; Drescher et al., 1995; Donoghue et al., 1996; Flenniken et al., 1996; Zhang et al., 1996; Frisén et al., 1998), whereas EphA3, EphA4, EphA5, EphA7, and EphA8 have all been reported to be expressed in an anterior $>$ posterior gradient (Ciossek et al., 1995; Flenniken et al., 1996; Park et al., 1997; Connor et al., 1998). The identification of these candidate-mapping labels allows the chemoaffinity hypothesis to be functionally characterized at the molecular level. Gain-of-function studies show that ephrin-A2 and ephrin-A5 are sufficient to repel chick or mouse retinal axons with a topographically specific preference for temporal retinal axons in vivo (Nakamoto et al., 1996) and in vitro (Nakamoto et al., 1996; Monschau et al., 1997; Feldheim et al., 2000), showing that they have properties expected of topographically specific guidance factors in the target. In addition, ectopic expression of ephrin-A2 or ephrin-A5 in nasal retina appears to mask or downregulate EphA receptor function and, therefore, may also be important in the retina for map formation (Hornberger et al., 1999; Feldheim et al., 2000).

In loss-of-function studies of ephrin-A2 or ephrin-A5, when either gene is disrupted, moderate map disturbances are seen, demonstrating both overlapping and distinct functions for these two ephrins in retinotectal mapping (Frisén et al., 1998; Feldheim 
et al., 2000). After double knock-out of both these ephrins, topographic order along the anteroposterior axis is more severely disrupted in vivo, and SC-derived repellent activity was undetectable by the in vitro stripe assay (Feldheim et al., 2000). A notable feature of the ephrin-A mutants is that although temporal axons shift posteriorly in the target, as expected from removal of targetbased repellents, nasal axons tend to shift in the opposite direction, anteriorly. Two models have previously been proposed to account for this anterior shift. One is based on receptor masking by ephrins in nasal retina and proposes that the anterior shift may be attributable to increased sensitivity of nasal axons to remaining repellents in the target (Hornberger et al., 1999; McLaughlin and O'Leary, 1999; Feldheim et al., 2000; Wilkinson, 2000). Consistent with this model, nasal axons from ephrin mutants do have greatly increased in vitro sensitivity to posterior SC membranes (Feldheim et al., 2000). An alternative model is based on axonaxon competition, proposing that the anterior shift by nasal axons may be explained by competition with other retinal axons that terminate in the posterior tectum when repellent ephrins are removed (Feldheim et al., 2000). This second explanation for the mutant phenotype is consistent with a model for topographic mapping that would rely on graded topographically specific labels, in combination with axon-axon competition for space in the target (Fraser and Hunt, 1980; Goodhill and Richards, 1999; Brown et al., 2000; Feldheim et al., 2000; Goodhill, 2000).

Although A ephrins have been studied the most extensively in mapping, other molecules are also likely to have important roles. RGM1 has recently been cloned as a molecule with topographically specific repellent activity in vitro and is expressed in an A-P gradient in chick tectum (Monnier et al., 2002). In addition, members of the B ephrin family and their receptors have been shown to be important for mapping of retinal axons along the dorsal-ventral axis (Hindges et al., 2002; Mann et al., 2002). It is also worth noting that, in addition to a forward signal through the Eph receptors, ephrins have the potential to act bidirectionally, with a reverse signal transduced through the ligands. Reverse signaling has been characterized extensively for the transmembrane B ephrins (Henkemeyer et al., 1996; Holland et al., 1996; Bruckner et al., 1997; Mellitzer et al., 1999, 2000; Birgbauer et al., 2000; Lu et al., 2001) and also appears to occur in the glycosyl phosphatidylinositol lipid-anchored A ephrins (Davy et al., 1999; Davy and Robbins, 2000; Hattori et al., 2000; Knoll et al., 2001), and it has been proposed to play a role in neuromuscular and olfactory map development (Feng et al., 2000; Knoll et al., 2001; Cutforth et al., 2003).

Here, we describe a loss-of-function analysis of EphA receptors in retinal axon mapping. This was done by using both a truncated receptor approach in chick and by gene targeting in mouse. The results were analyzed by testing both retinal axon guidance in vitro and axon mapping in vivo. Retinas from EphA5 mutant mice, or chick retinas retrovirally transduced with a cytoplasmically truncated EphA3 receptor, showed reduced responsiveness to posteriorly derived repellent activity in vitro. In chick, ectopic expression of patches of truncated EphA3 in the retina caused abnormally posterior mapping of temporal axons. In mice with a targeted mutation in EphA5, both temporal and nasal axons mapped to incorrect locations, with temporal axons terminating in abnormally posterior regions and nasal axons in abnormally anterior regions, although the entire target area was still filled by incoming axons. Taken together, these studies show that endogenous EphA receptors are required for normal mapping, indicate that forward signaling requires the intracellular domain of the receptor for a normal response of retinal axons to topographic cues, support a repellent signaling function for EphA receptors, and provide new support for a role of competition in topographic mapping.

\section{Materials and Methods}

Expression pattern analysis and in vitro stripe assay. Hybridization probes for mouse EphA5 (Feldheim et al., 1998) and EphA6 (Maisonpierre et al., 1993) have been described. In situ hybridization was performed as described (Feldheim et al., 1998). Affinity probe in situ using EphA3-AP, EphA4-AP, EphA5-AP, and ephrin-A5-AP fusion proteins was also as described previously (Feldheim et al., 1998). Fixed cryostat sections were stained for $\beta$-galactosidase expression as described by Henkemeyer et al. (1996).

The membrane stripe assay (Walter et al., 1987a) was performed as described previously for chick (Nakamoto et al., 1996) and mouse (Feldheim et al., 1998).

Axon tracing in EphA5 gene-targeted mice. For tracing in mice, the eyelid was cut open to expose the eye, and $0.1-1 \mathrm{ml} \mu \mathrm{l}$ of $10 \% \mathrm{DiI}$ in dimethyl formamide was injected into at the temporal or nasal extreme of the retina with a fine glass micropipette using a Picospritzer II (General Valve, Fairfield, NJ). One to two days later, at postnatal days (P) 12-20, mice were analyzed blind to genotype, and a piece of tail was taken for later genotyping. The age distributions of the wild-type and mutant groups were similar. Grouping mutant mice by age, mapping abnormalities were seen in 27 of 52 mice at P12-P14 and 10 of 19 mice at P15-P20 ( $p=0.97$; Mann-Whitney $U$ test). After fixation by cardiac perfusion with $4 \%$ paraformaldehyde in PBS, midbrains were photographed with fluorescence optics as whole mounts and then as $200 \mu \mathrm{m}$ vibratome sections. Axon arborizations were confirmed by their appearance at high magnification on whole mounts and sections. The SC boundaries were identified by their characteristic shape and location under visible light or by autofluorescence. All injected retinas were photographed as flat mounts. Because there is no prominent optic fissure in mice, orientation was determined according to the initial injection site. There was no obvious difference in the size, location, or appearance of the labeling sites, or in the size of the retinas, that could account for the differences in the mutant projections. Whole-eye fills with fluoresceinated cholera toxin were performed as described (Feldheim et al., 2000).

The $5^{\prime}$ and $3^{\prime}$ fragments used in construction of the targeting vector were isolated from a 129SV mouse genomic library in the lambda FixII vector (Stratagene, La Jolla, CA) and cloned into the vector pKOVpLacZ, which comprises the LacZ gene, followed by the phosphoglycerate kinase promoter-driven neomycin resistance gene ( $P G K-\mathrm{Neo})$ for gene targeting in embryonic stem cells as described (DeChiara et al., 1995). Genotyping of EphA $5^{\text {lacZ }}$ mice was done by PCR of genomic DNA obtained from tails using primer GCCCGTTATGAAAGTGCATCTTTTCC immediately downstream of the fusion point in exon 8 of EphA5, the first exon after the transmembrane domain, and primer ACTGGCATGGAAATTGGCTCTGG in intron 7 upstream of the fusion point, to detect the wild-type gene and the neo primer GCAACTGTTGGGAAGGGCGATC. The wild-type allele yields a $200 \mathrm{bp}$ product, and the mutant allele a 300 bp product.

Retroviral constructs and axon tracing in chick. RCAS-EphA3 $\Delta \mathrm{C}$ has been described (Nishida et al., 2002). Titers of the retrovirus stocks used in the present studies were $1-5 \times 10^{8} \mathrm{ml}^{-1}$ for RCAS-EphA3 $\Delta$ C. For axon tracing experiments, retroviral stock with dye tracer was injected into the right optic vesicle of embryonic day (E) 2 [Hamburger and Hamilton (HH) stages 10-12] chicken embryos in windowed eggs. Retinal axons were anterogradely labeled with DiI (Molecular Probes, Eugene, OR) on E16, and labeled axons were analyzed on E18 (HH stages 40-42), as described previously (Nakamoto et al., 1996).

\section{Results}

Mapping in mice with targeted mutation in EphA5 receptor

To test whether EphA5 is required for proper retinocollicular development, we examined mice with a targeted gene disruption. The targeted allele, EphA $5^{\text {lac } Z}$, is designed to encode a fusion protein consisting of the extracellular, transmembrane, and jux- 
tamembrane domains of EphA5 linked to $\beta$-galactosidase. This EphA5- $\beta$-galactosidase fusion receptor is missing the entire tyrosine kinase and C-terminal domains of EphA5. Mice carrying this allele should be both mutant in EphA5 and have $\beta$-galactosidase activity in cells that normally express EphA5. Because the EphA $5^{\text {lac } Z}$ allele replaces the intracellular domain but leaves the extracellular domain intact, it is likely that kinaseindependent functions for EphA5 remain intact, as reported for an analogous lacZ fusion of an EphB class receptor (Henkemeyer et al., 1996; Birgbauer et al., 2000). EphA5 $5^{\text {lacZ/lacZ }}$ mice reach adulthood, are fertile, and show no gross morphological defects.

To assess the effects of EphA5 gene disruption on retinocollicular mapping, a focal injection of DiI was made in one retina, followed by examination of the contralateral midbrain. When retinal axons near the temporal extreme of wild-type mice were labeled, a characteristic arborization was seen at the anterior extreme of the SC (Fig. 1A). When temporal axons of EphA $5^{\text {lacZ/lacZ }}$ mice were labeled, an apparently normal arborization was always seen, and in approximately half the animals (51\% penetrance; 23 of 45 mice), additional more posterior arborizations were seen (Fig. 1C,D). In some cases (15 of 45), additional dye labeling localized to the extreme SC-inferior colliculas (IC) border (Figs. $1 D, 2 E)$.

When axons near the nasal extreme of the retina were labeled, wild-type mice always showed a single arborization near the posterior end of the SC (Fig. $1 F)$. EphA5 $5^{\text {lacZllac }}$ mice showed an apparently normal arborization near the posterior end of the SC, and in approximately half the mutants there were additional arborizations in more anterior locations (42\% penetrance; 6 of 14 mice) (Figs. $1 \mathrm{H}, 1 \mathrm{I}$ ). No comparable phenotypes of either temporal or nasal axons could be detected in EphA $5^{\text {lacz/+ }}$ heterozygotes ( 0 of 20 mice) (Figs. $1 B, 1 G$ ), although we cannot rule out more subtle defects that would not be seen by the methods used here.

Up to four distinct arborizations were seen in the SC of individual mutants, with the average number of arborizations being $2.0 \pm 1.17$ (mean $\pm \mathrm{SD}$ ) for nasal labelings and $1.6 \pm 0.77$ for temporal labelings. The ectopic terminations generally extended within the same A-P half of the SC as in wild-type mice and did not appear to be targeted to any specific ectopic position. In a few cases (three of the six EphA $5^{\text {lacZ } / l a c Z}$ mice that had ectopic nasal axon arborizations), the ectopic arborizations seemed to have slight dorsoventral errors, suggesting that EphA5 may also play some role in mapping this axis (Fig. $1 H$ ).

DiI injections were made approximately at the midpoint of the nasotemporal axis in other mutant animals. Such labelings revealed multiple arborizations in most cases (75\% penetrance; 8 of 12 animals) (Fig. 2A). Although it is not possible to be certain which, if any, of these multiple arborizations were "normal," there was always a particularly bright spot at the topographically expected position and additional fainter spots displaced in anterior or posterior directions (Fig. $2 \mathrm{~A}$ ).

Because labelings were analyzed over a fairly broad range of ages, it was of interest to see whether the time of labeling had an effect on the results. Grouping all EphA $5^{\text {lacZ/lac Z }}$ labelings by age, mapping abnormalities were seen in 27 of 52 mice at P12-P14 and 10 of 19 mice at P15-P20, similar in each case $(p=0.97$; Mann-Whitney $U$ test). The results, thus, provided no indication that the phenotype is attributable to a developmental delay or is corrected within this period.

To test whether retinal axons fill their target areas, we injected fluoresceinated cholera toxin subunit into the eye to label ganglion cells throughout the retina. The results show that in

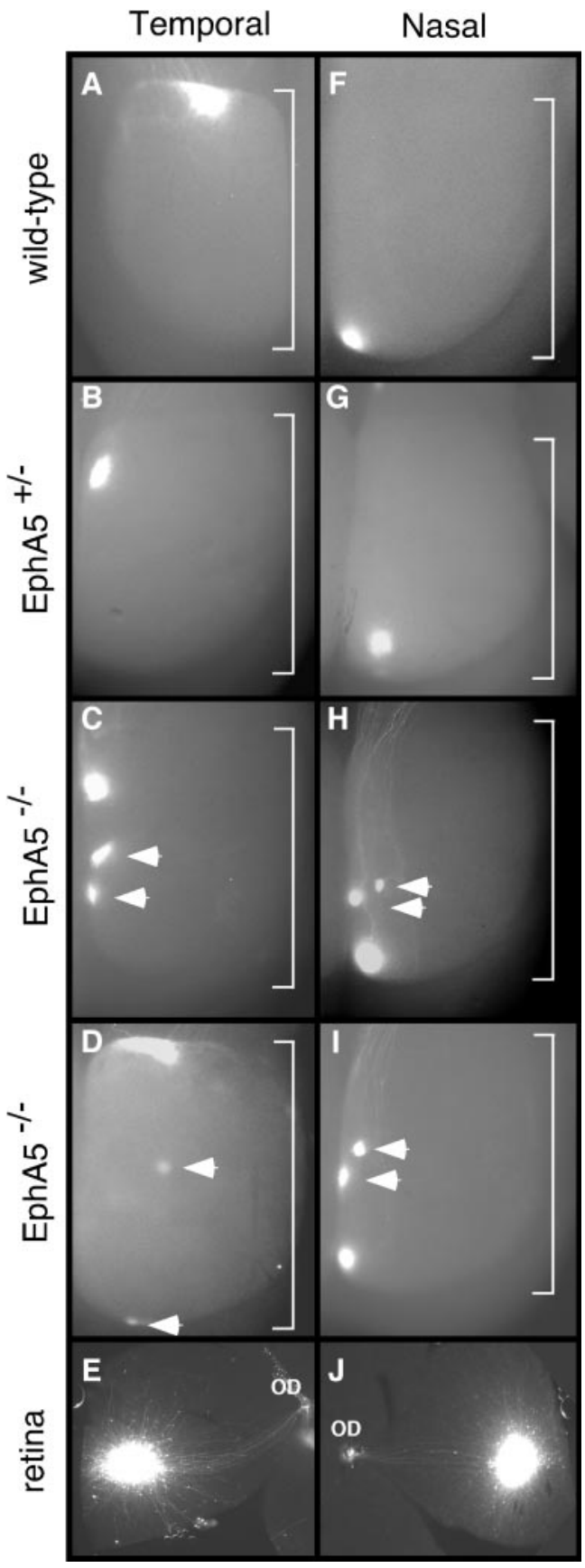

Figure 1. Mapping abnormalities in the $S C$ of EphA5 $5^{\text {Iacz/lacz }}$ mutant mice. Retinal axons labeled by focal Dil injection were visualized at P14 by florescence microscopy of $\mathrm{SC}$ whole mounts. The brackets indicate SC; anterior is at the top. $A-D$, Temporal injections. Temporal retinal injections in wild-type $(A)$ or EphA $5^{\text {lacz/+ }}$ heterozygous $(B)$ mice show an arborization in the anterior portion of the SC. Similar injections in EphA5 lacZ/lacZ mutants $(C, D)$ show ectopic arborizations posterior to the normal location. $F-I$, Nasal injections. Nasal retinal injections in wild-type $(F)$ or EphA5 $5^{\text {lacz/+ }}$ heterozygous $(G)$ mice show arborizations at the posterior extreme of the SC. EphA5 ${ }^{\text {lacz/lacz }}$ mutants show ectopic arborizations anterior to the normal site. In addition to ectopic spots, all labelings in the EphA ${ }^{\text {IacZ/lacz }}$ mutants showed a prominent arborization at the normal location. The arrows indicate ectopic arborizations. $E$, J, Temporal or nasal retinal quadrants, respectively, showing typical labeling sites. Axons exit the retina at the optic disc (OD).

EphA $5^{\text {lacZ/lacZ }}$ mice the RGCs still reach and fill the entire SC (Fig. $2 C, D)$. Parasagittal sections across the midbrain in mutant animals reveal that the ectopic arbors seem morphologically similar to normal ones and that EphA5 is not essential for targeting to the 


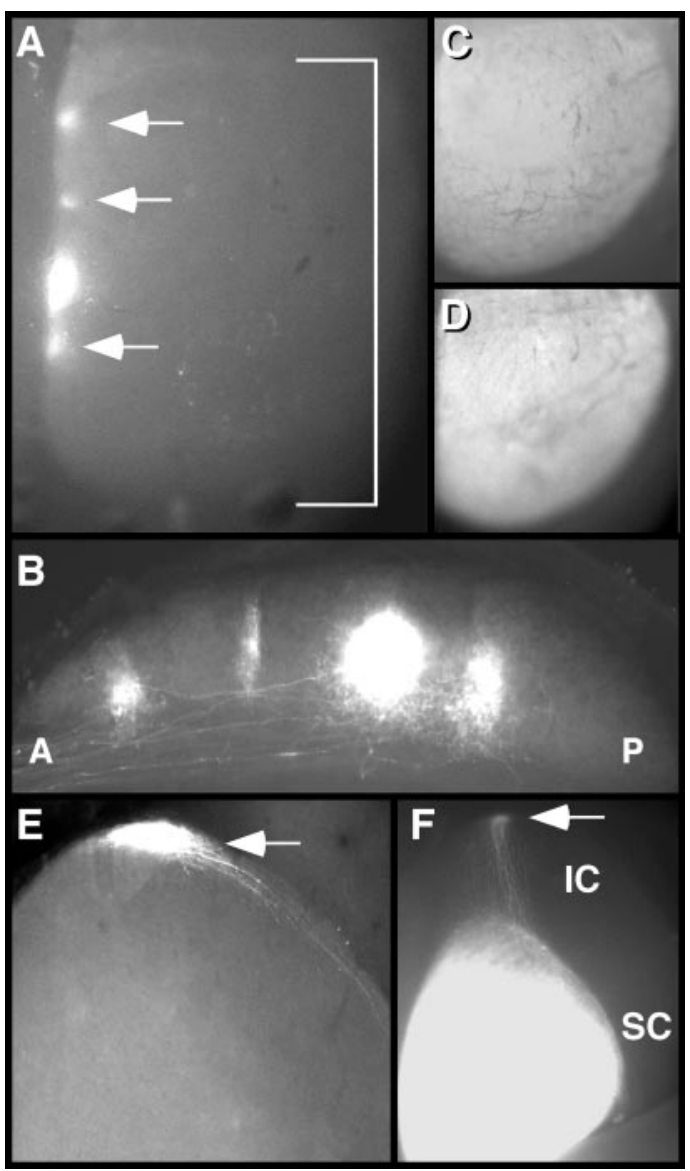

Figure 2. Analysis of the visual projections in EphA $5^{\text {Iacz/lacz }}$ mice. $A$, Axons labeled approximately in the middle of the nasal-temporal axis by focal Dil injections in ventral retina were

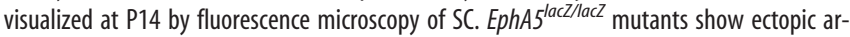
borizations both anterior and posterior to the expected location. The arrows indicate likely ectopic arborizations. A bracket indicates the anterior and posterior boundaries of the SC. $B_{\text {, }}$ Parasagittal section through the $S C$ shown in $A$. Ectopic arborizations branch to the correct layer of the SC. C, D, Eye fill with fluoresceinated cholera toxin $\beta$ subunit to anterogradely label projections throughout the retina. Labeled axons fill the SC in both wild-type and EphA $5^{\text {Iacz/lacz }}$ mutant animals in $C$ and $D$, respectively. $E$, Horizontal section through the midbrain of an $E p h A 5^{\text {IacZlacZ }}$ mouse given an injection in the temporal retina. Axons can be seen at the extreme SC-IC border (arrow indicates path of axons along the lateral extreme of the SC). F, Wholemount view of $\mathrm{P} 3$ mouse $\mathrm{SC}$, after eye fill with Dil at $\mathrm{P} 2$. The arrow indicates axons passing through the SC to the posterior extreme of the IC.

correct layer of the SC (Fig. $2 B$ ). In addition to effects within the SC map, the EphA $5^{\text {lacZ/lacZ }}$ mutation causes an abnormal overshooting of retinal axons into the IC at early developmental stages (Fig. $2 F$ ), apparently similar to the overshooting previously noted in ephrin-A5 ${ }^{-1-}$ mutants (Frisén et al., 1998).

In principle, mapping abnormalities could result not from a loss of EphA5 function, but only from a dominant-negative effect of the EphA $5^{\text {lac } Z}$ allele on a different Eph receptor, but this seems unlikely, especially because no dominant phenotype was observed in EphA5 $5^{\text {lacZ/+ }}$ heterozygotes. It is also possible that the phenotype could be explained by a role for EphA5 in establishing a tangential pattern of the retina or SC, rather than a direct role in axon guidance. To address this, we tested the EphA $5^{\text {lac } Z / l a c Z}$ mice for expression of $\beta$-galactosidase as well as regional markers. EphA5 is expressed in a temporal >nasal gradient in the RGC layer of the mouse embryo (Feldheim et al., 1998) (Fig. 3A). Sections derived from EphA5 $5^{\text {lacZllacZ }}$ mice and stained for $\beta$-galactosidase activity show a temporal $>$ nasal gradient of ex-

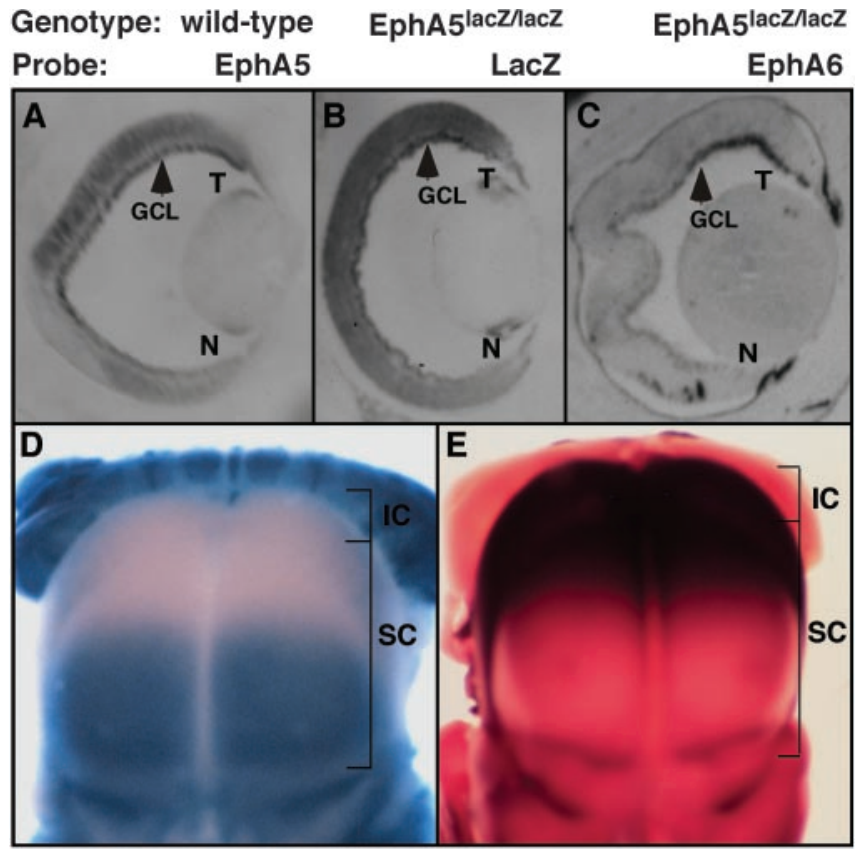

Figure 3. Patterning of the retina and SC in EphAs ${ }^{\text {laczllacz }}$ mice. $A-C$, Horizontal sections through the P0 eye from wild-type $(A)$ or $E p h A 5^{\text {lacZ/lacZ }}(B, O)$ mice. $A$, EphA5 receptor RNA is in a temporal $>$ nasal gradient in wild-type retina. $B$, EphA5 detected by $\beta$-galactosidase staining in EphA5 $5^{\text {lacz/lacZ }}$ remains in a temporal $>$ nasal gradient. C, EphA6 receptor RNA is also in a temporal $>$ nasal gradient in EphA5 ${ }^{\text {IacZ/lacZ }}$ mutant retinas. D, E, Midbrains in EphA5 ${ }^{\text {IacZ/lacZ }}$ mice are patterned normally. D, Whole-mount $\beta$-galactosidase staining of EphA5 $5^{\text {lacz/lacz }}$ mutant midbrain is in an anterior $>$ posterior gradient. $E$, Ligand expression detected by binding of an

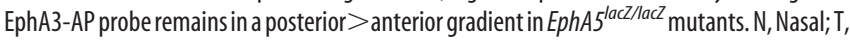
temporal; $\mathrm{GCL}$, ganglion cell layer. The brackets indicate the $\mathrm{SC}$ and IC regions of the midbrain.

pression in the RGC layer of the retina (Fig. $3 B$ ), which is similar to that seen in EphA $5^{\text {lacz/+ }}$ heterozygous mice (data not shown). EphA6 is also known to be in a temporal >nasal gradient across the mouse retina (Feldheim et al., 2000). This gradient was still present in EphA5 $5^{\text {lacZ/lacZ }}$ mutants (Fig. $3 C$ ). In the mouse SC, ephrin-A2 and ephrin-A5 are expressed in a posterior $>$ anterior gradient, and this gradient can be detected with an EphA3-AP fusion protein (Cheng et al., 1995). We find that this binding gradient is still present in the EphA5 $5^{\text {lacZ/lacZ }}$ mutant (Fig. $3 E$ ). Although the possibility of a subtle patterning difference cannot be eliminated, there did not appear to be any major change in the graded patterning of cell fates in the retina or tectum that could account for the mapping phenotype.

\section{Effect of EphA5 mutation on response to repellent activity in vitro}

In addition to the prominent EphA5 expression in the RGC layer of the retina, we found EphA5- $\beta$-galactosidase expression in the SC of EphA $5^{\text {lac Z/lac Z }}$ mice in an anterior $>$ posterior gradient (Fig. $3 D$ ). This expression is consistent with previous studies showing EphA receptors localized in this manner in the SC (Ciossek et al., 1995; Flenniken et al., 1996; Park et al., 1997; Connor et al., 1998; Marin et al., 2001). Therefore, tests for mapping abnormalities in vivo in the mutant mice do not resolve whether EphA5 acts in the $\mathrm{SC}$, the retina, or both. To examine this, we performed in vitro stripe assays in a mix-and-match format in which either the retinal explants or the SC membranes were taken from wild-type or mutant mice.

In the first series of experiments, we tested whether EphA5 is required for the detection of repellent activity in the SC. It has 
previously been shown in chick (Walter et al., 1987b), mouse (Godement and Bonhoeffer, 1989), and rat (Simon and O'Leary, 1992; Roskies and O'Leary, 1994) that membranes from posterior tectum/SC will repel retinal axons or inhibit their branching in a topographically specific manner and that ephrin-A2 and ephrin-A5 are sufficient for this activity in vitro (Nakamoto et al., 1996; Monschau et al., 1997). EphA receptors are predicted to be involved in the response, based on several lines of evidence, including retinal expression gradients (Cheng et al., 1995; Feldheim et al., 1998, 2000; Brown et al., 2000), the addition of soluble ligand or receptor fusion proteins in vitro (Ciossek et al., 1998), antibody or dominant-negative inhibition in vitro of chick EphA4, a receptor that is not graded but seems to be involved in retinal responses (Walkenhorst et al., 2000), and ectopic expression of EphA3 in mouse retina (Brown et al., 2000). To test by a genetic loss-of-function approach the requirement of EphA5 in the retinal axon response, we performed stripe assays comparing mutant or wild-type retinal axons growing on membranes from wild-type SC (Fig. 4). Wild-type mouse posterior SC membranes repelled temporal explants derived from wild-type or EphA $5^{\text {lacz/+ }}$ heterozygous retinas (Fig. $4 A, C, E$ ). However, when temporal explants were derived from $E p h A 5^{\text {lacZ/lac } Z}$ mutant mice, they showed a much reduced responsiveness to posteriorly derived SC membranes compared with wild type temporal axons $(p<0.001)$ (Fig. 4D,E). The responsiveness of the mutant temporal axons to recombinant ephrin-A2 or ephrin-A5 was also reduced (data not shown). Nasal axons showed no obvious change in the EphA $5^{\text {lacZ/lacZ }}$ mutant, remaining unresponsive to SC membranes (Fig. 4E).

We also tested by genetic loss-of-function whether EphA5 has a role in the SC. To do this, we performed stripe assays with wild-type retinal axons growing on membranes from wild-type or mutant SC. In both cases, posterior-derived membranes repelled temporal, but not nasal, axons, similar to the result with wild-type-derived membranes (Fig. $4 B, E$ ). We cannot rule out a subtle change in the guidance properties of SC membranes, and in principal, it might be expected that removal of receptor might unmask some ephrin activity in the SC. However, because the $E p h A 5^{\text {lac } Z}$ allele only removes the intracellular portion of the molecule, it seems likely that any masking of ephrin activity in the SC would remain in the mutants. Within the limits of our analysis, the differential repellent properties of posterior versus anterior SC appeared intact in the mutant.

\section{Ectopic expression of cytoplasmically truncated EphA3 in chick}

As an independent test of receptor function in topographic mapping, we used a misexpression approach with the RCAS retroviral vector in chick retina (Fekete and Cepko, 1993). The receptor patterns in chick and mouse differ, and unlike in mouse where EphA3 expression has not been detected in RGCs, in chick the EphA3 receptor is in a prominent nasotemporal gradient across the RGC layer and was proposed to act as a topographically specific label (Cheng et al., 1995). We previously found that viral overexpression of ephrin-A2 patches in chick tectum causes avoidance by temporal retinal axons (Nakamoto et al., 1996). Here, we tested the effect of a truncated EphA3 receptor, using the virus RCAS-EphA3 $\Delta$ C. This vector encodes an EphA3 receptor lacking most of the intracellular region, including the tyrosine kinase domain (Nishida et al., 2002). Such truncated receptors are expected to act in a dominant-negative manner by heterodimerizing with endogenous receptors or by sequestering ligand, and although the specific mechanism was not tested here,
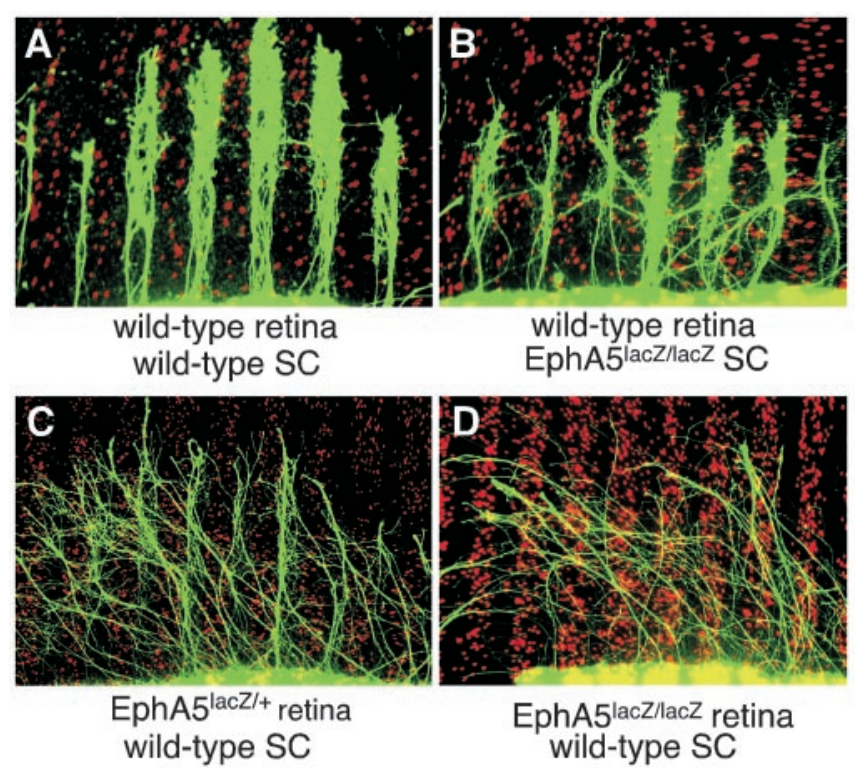

E

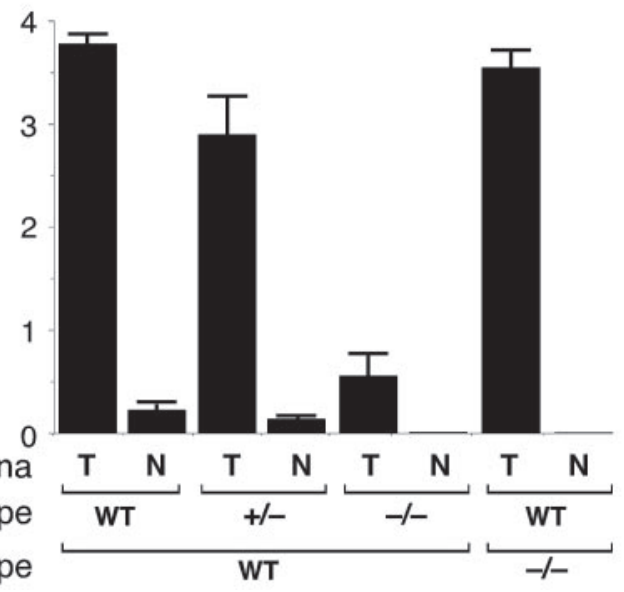

Figure 4. Mix-and-match stripe assays of retina and SC from EphA5 $5^{\text {lacz/lacz }}$ or wild-type mice. $A, B$, Repellent activity in the SC of EphA $5^{\text {lacZ/lacz }}$ mice. Temporal axons from wild-type mice were tested with alternating anterior and posterior stripes of $S C$ membranes from wildtype $(A)$ or EphA5 lacz/lacz $(B)$ mice. $C, D$, Loss of responsiveness of temporal axons from $E_{\text {EhA5 }}^{\text {lacz/+ }}$ and EphA5 $5^{\text {lacz/lacz }}$ mutant mice. Temporal axons from EphA5 ${ }^{\text {lacz/+ }}(C)$ or EphA5 $5^{\text {lacz/ }}$ $\operatorname{lacz}(D)$ mice were grown on alternating anterior and posterior SC stripes from wild-type mice. $E$, Results of mix-and-match stripe assays using retina or SC from wild-type (WT) or EphA5 $5^{\text {lacz/lacZ }}$ mice. Axon preference for anterior SC lanes was scored on a scale of 0 (no preference) to 4 (strong preference). The bars show means \pm SEM. N, Nasal; T, temporal. Axons are shown in green; red fluorescent microspheres mark posterior SC stripes.

this approach has been used widely for Eph receptors and other receptor tyrosine kinases (van der Geer et al., 1994; Xu et al., 1995; Lackmann et al., 1998; Holmberg et al., 2000).

A virus was injected into the optic cup of chick embryos at E2 in ovo. Because the virus was injected into the optic cup, which protrudes laterally from the main neural tube, it was relatively easy to restrict the virus infection in the retina. This was confirmed by incorporating dye with the injected virus solution, and, in addition, several embryos were tested by in situ staining with an EphA3-AP probe, confirming that ectopic expression could not be detected in the tectum or elsewhere outside the retina. As judged by in situ hybridization for EphA3 RNA sequences, much of the retinal surface was infected, with the extent varying in different embryos. The distribution was patchy, and within these patches EphA3 RNA levels were higher than the endogenous ex- 

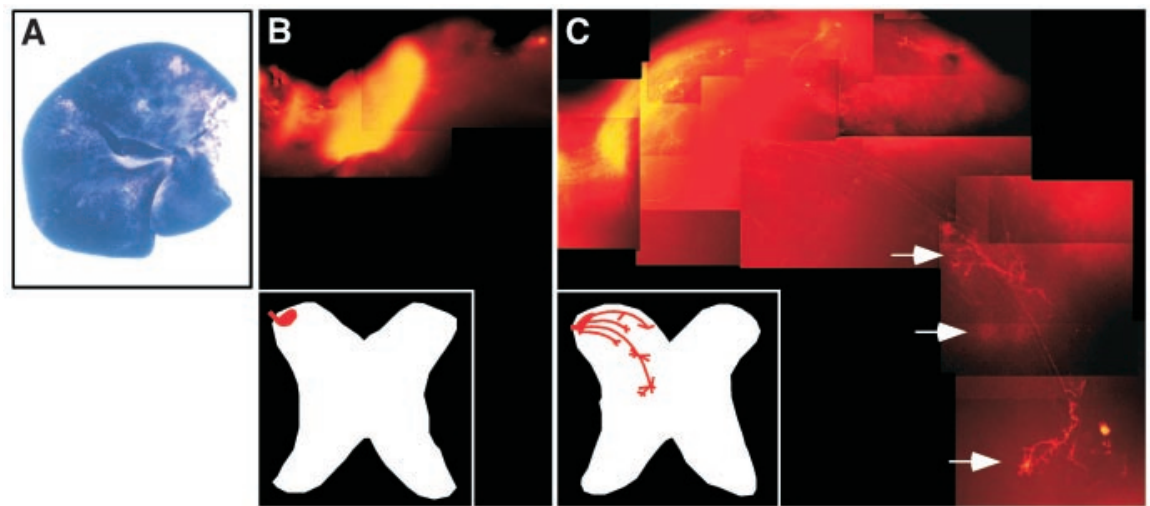

Figure 5. Cytoplasmically truncated EphA3 leads to mapping and guidance errors of temporal retinal axons. A, Pattern of retroviral vector infection in chick retina. Whole-mount in situ hybridization with an EphA3 RNA probe to detect EphA3 $\Delta$ C on chick retinas after injection of virus into the optic cup atE2. This is an example with a relatively extensive expression of exogenous EphA3 RNA; in other cases, patches were sparser. $B, C$, Truncated EphA3 leads to mapping and guidance errors of temporal retinal axons. Temporal retinal axons were labeled by Dil and visualized by fluorescence microscopy as whole-mount chick tectum. $B$, Wild-type temporal axons map to the anterior tectum. C, Temporal axons infected with RCAS-EphA3 $\Delta$ C project to abnormally posterior locations in the tectum. Arrows indicate ectopic arbors. Insets show schematic view of labeled axons with respect to the tectum. abnormal locations, as well as a termination zone at the expected location (Fig. $5 C)$. The ectopic arborizations were more posterior than the normal location, with no indication of obvious dorsoventral defects. In most cases, the ectopic arbors were located in the same two-thirds of the tectum as the normal termination site and never reached all the way to the posterior end. Our results appear consistent with the idea that the mistargeted temporal axons are the same ones that express EphA3 $\Delta \mathrm{C}$, although attempts to show this directly were unsuccessful using several different marker strategies in this chick retroviral expression system (data not shown). We found no obvious abnormalities of nasal axons under the same conditions ( 0 of 5 embryos; $p<0.05$ ). However, an undershooting phenotype of nasal axons might be harder to detect than the overshooting phenotype of temporal axons, and we can-
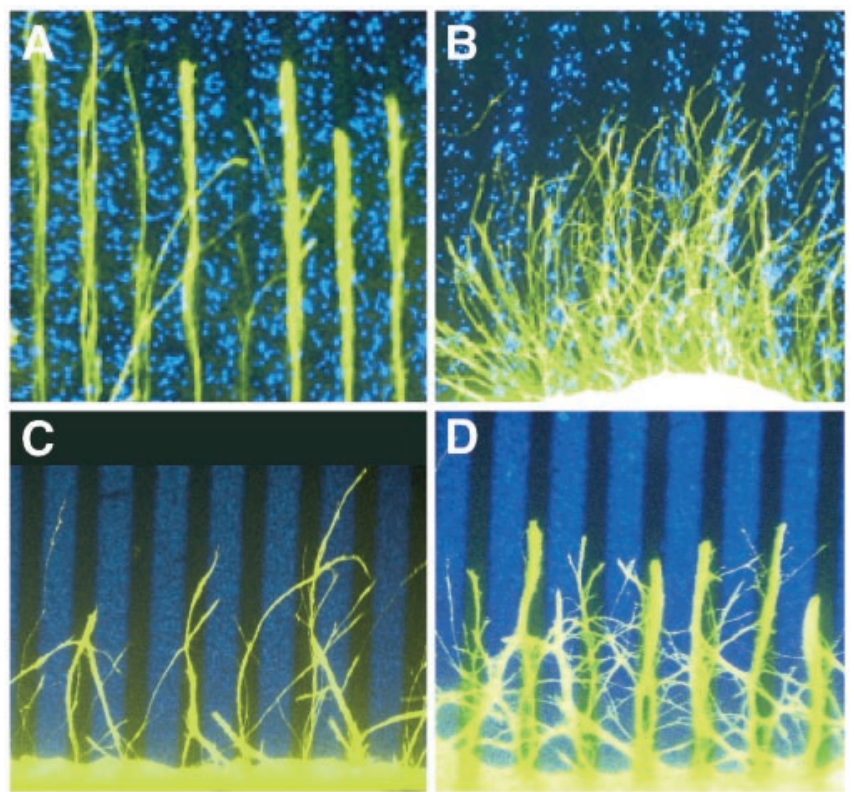

Figure 6. Stripe assay of axons from RCAS-EphA3 $\Delta$ C-infected or normal chick retina. Explants from temporal retina were placed on membrane carpets consisting of alternating stripes of membranes derived from anterior or posterior tectum. Preference for anterior lanes was scored blind on a scale of 0 (no detectable preference) to 4 (strong preference). $A$, Temporal axons from normal chick retina prefer anterior stripes to posterior stripes (score, 4). $B-D$, Temporal axons from chick retina infected with RCAS-EphA $3 \Delta$ C virus tended to show a reduced preference. The results were somewhat variable, sometimes even within a single explant, perhaps reflecting patchy virus infection. $B$ shows an extreme example with axons growing similarly over both anterior and posterior stripes (score, 0 ), whereas $C$ (score, 2) and D (score, 3) show intermediate examples. Axons are shown in green; blue fluorescent microspheres mark posterior tectal stripes, and smaller microspheres were used in $C$ and $D$.

pression, as seen on whole mounts (Fig. 5A) or sections (data not shown). At E16, DiI was focally injected into nasal or temporal extremes of the retina, and the projections were visualized as whole mounts at E18.

In embryos injected with truncated EphA3 receptors, when retinas were labeled in the temporal extreme, we found clear mapping errors. In most cases ( 9 of 15 embryos; different from wild type with $p<0.001$ ), there were additional terminations in not rule out the possibility of a nasal axon phenotype that was not detected here.

We also tested the effects of these viral constructs on axon guidance, using an in vitro stripe assay (Fig. 6). When retinal axons were traced after being infected with the RCAS-EphA3 $\Delta \mathrm{C}$ virus, temporal axons showed significantly reduced responsiveness to posterior tectal membranes (temporal axons from EphA3 $\Delta$ C infected retina: mean score, 1.16; SD, 1.12; SEM, 0.26; $n=19$; control temporal axons: mean score, 2.88 ; SD, 0.64 ; SEM, $0.23 ; n=8 ; p<0.001$ ) (Fig. 6). These results are consistent with the effect of the RCAS-EphA $3 \Delta \mathrm{C}$ virus on temporal mapping in vivo and with the idea of a repellent forward signaling function for EphA3 and possibly other EphA receptors in retinal axons.

\section{Discussion}

Eph receptors and their ligands, the ephrins, are thought to act as positional labels for the establishment of topographic maps (Drescher et al., 1997; Flanagan and Vanderhaeghen, 1998; O'Leary and Wilkinson, 1999; Feldheim et al., 2000). Much of this analysis has come from the study of the projection of visual information from the retina to the tectum, or its mammalian equivalent the SC. The existing loss-of-function analysis has so far focused mainly on the role of ephrins in this projection. Here, loss-offunction approaches are used to characterize the role of EphA receptors in retinotectal mapping in both mouse and chick.

\section{Loss-of-function shows endogenous EphA receptors are} required for proper topographic guidance in vitro and in vivo The expression of EphA receptors in temporal >nasal gradients, EphA3 in chick (Cheng et al., 1995) and EphA5 and EphA6 in mouse (Feldheim et al., 1998, 2000), initially led to the idea that these graded EphA receptors may act as topographically specific labels in the retina. Here, we demonstrate that gene targeting of the EphA5 tyrosine kinase domain in mouse results in topographically specific mapping errors in both temporal and nasal axons showing by loss-of-function that EphA receptor action is required for proper map development in vivo. We also demonstrate that retinal axons derived from the EphA5 gene-targeted mice lose much of their responsiveness to posterior SC membranes in vitro, demonstrating a requirement for forward EphA receptor signaling in topographically specific axon guidance. Our 
loss-of-function experiments in chick support a similar conclusion. A truncated version of EphA3, which is presumed to heterodimerize with and inactivate endogenous receptors (van der Geer et al., 1994; Xu et al., 1995; Lackmann et al., 1998; Holmberg et al., 2000), was retrovirally expressed in chick retina. Temporal retinal axons showed a reduction in responsiveness to posterior tectal membranes in vitro and mapped to abnormally posterior tectal positions in vivo. Although it may seem somewhat surprising that the topographic receptors used in mouse versus chick would be different, because one would generally expect orthologous molecules to have a conserved function, rapid evolutionary shifts from one ephrin to another have been seen in other systems (Wang and Anderson, 1997). In the retinotectal system, the analysis here provides functional support for the idea that, although the combination of EphA receptors expressed in chick and mouse retina differs, retinal EphA receptors including EphA5 in mouse and EphA3 in chick appear to have similar functions in mapping.

\section{Comparison of EphA5 gene-targeting phenotype ephrin-A phenotypes}

The retinocollicular map in the EphA $5^{\text {lacZ/lacZ }}$ mutant is similar to the ephrin- $A 5^{-1-}$ single knock-out mouse in both pattern and frequency of defects. This phenotype is not as penetrant or severe

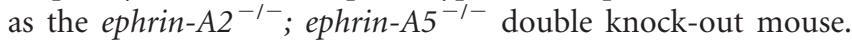
The incomplete loss of map topography in ephrin-A5 ${ }^{-1-}$ mice can be explained by partial redundancy with ephrin-A2, and possibly other guidance molecules such as RGM. Likewise, the partially penetrant phenotype of the EphA5 mutant could be explained by partial redundancy in the retina, because an overlapping temporal $>$ nasal gradient of EphA6 is present in the RGC layer and is maintained in the EphA $5^{\text {lacZ/lac Z }}$ mutant.

The close similarities between the EphA $5^{\text {lacz/lac } Z}$ phenotype and the ephrin- $A 5^{-1-}$ single knock-out phenotype are intriguing. Just as observed here in EphA5 ${ }^{\text {lac Z/lacZ }}$ mice, temporal axon labelings in ephrin- $A 5^{-1-}$ mice revealed arborizations at the correct location, as well as somewhat more posterior ectopic arborizations in about half the mice and additional arborizations at the SC-IC boundary (Frisén et al., 1998), whereas nasal axon labelings revealed arborizations at the correct location and more anterior ectopic arborizations in about half the mice (Feldheim et al., 2000).

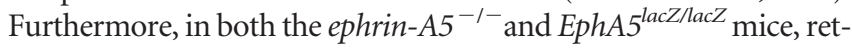
inal axons overshoot abnormally into the IC at early stages of mapping (Frisén et al., 1998). In contrast, ephrin-A2 ${ }^{-1-}$ mutants showed no indication of overshooting into the IC, or arborizations at the SC-IC boundary, or a nasal axon phenotype, or, in other words, none of the phenotypes seen in posterior midbrain in which ephrin-A5 expression is especially prominent (Feldheim et al., 2000). Although binding analyses have suggested a high degree of promiscuity in Eph-ephrin interactions, the close similarity of the EphA5 and ephrin-A5 mutant phenotypes provides genetic evidence that there could be a preferential functional relationship of this particular ligand-receptor pair in vivo.

\section{Tests of a model for mapping involving repulsion and competition}

Our ectopic expression studies in chick appear consistent with the idea that EphA3 can transduce a repellent signal. When EphA $3 \Delta \mathrm{C}$ was expressed in a subset of RGCs, temporal axons, which normally have high receptor levels, mapped to abnormally posterior positions in vivo and showed reduced responsiveness to tectal repellents in vitro. Likewise, in EphA $5^{\text {lacZ/lacZ }}$ mutant mice, temporal axons showed abnormally posterior mapping and lost much of their responsiveness to repulsion by posterior SC membranes in vitro.

However, this repellent model does not by itself account for the behavior of extreme nasal axons in the EphA $5^{\text {lacZ/lac } Z}$ mutant, because their terminations shift in the opposite, anterior direction in the SC. These considerations appear analogous to our

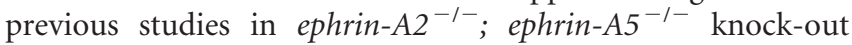
mice, in which nasal and temporal axons showed quantitatively similar, but opposite, shifts (Feldheim et al., 2000). Two different models to account for nasal axon mapping behavior have been proposed: a model involving masking of receptor by ligands in the retina (Hornberger et al., 1999; McLaughlin and O'Leary, 1999; Feldheim et al., 2000; Wilkinson, 2000) or a model based on axon competition (Brown et al., 2000; Feldheim et al., 2000). Incorporating the new data from the EphA $5^{\text {lacZ/lac } Z}$ mice helps in distinguishing these two models.

Supporting a receptor-masking model, we showed previously by genetic loss-of-function in mice that nasal axons from ephrin$A 2^{-1-}$; ephrin-A5 ${ }^{-1-}$ mutants have a strongly elevated response to posterior SC repellent activity in vitro (Feldheim et al., 2000). These results seem very consistent with previous studies in chick showing that retinal overexpression of ephrin-A5 causes axons to map more posteriorly and that treatment of the retina with phosphatidylinositol-specific phospholipase makes nasal axons more sensitive to ephrins in vitro (Hornberger et al., 1999). Those studies suggest ephrin-As in nasal retina mask retinal EphA receptors. Therefore, removal of the mask could explain why nasal axons shift anteriorly in the ephrin knock-out mutants (Hornberger et al., 1999; McLaughlin and O'Leary, 1999; Feldheim et al., 2000; Wilkinson, 2000).

However, it does not seem that this masking model can account for the comparable nasal axon shift seen here in EphA5 $5^{\text {lacZ/lacZ }}$ mice. In these animals, removal of the EphA5 tyrosine kinase domain should not decrease masking of receptors, and confirming this expectation, we saw no increase in the repellent responsiveness of nasal axons in vitro. In addition, the EphA $5^{\text {lacz/lac } Z}$ mutation is not expected to alter repellent activity in the SC, and consistent with this, we saw no change of receptor binding activity in the SC and no increase of posterior-derived in vitro repellent activity. We would like to emphasize that masking very likely contributes to the normal process of mapping, based on previous evidence (Hornberger et al., 1999; Feldheim et al., 2000). However, in view of the results here, it does not seem likely that the masking model can fully explain the anterior shift of nasal axons in the mutants, so an alternative explanation seems to be needed.

One model that may fit all our gain- and loss-of-function results involves a repellent gradient of ephrin, in combination with axon-axon competition for space in the target (Brown et al., 2000; Feldheim et al., 2000). Briefly, a repulsion/competition model could account for normal mapping as follows. Temporal axons have high EphA receptor and are strongly repelled by posterior ephrins, so that they terminate in the anterior SC. Nasal axons have low levels of receptor, so they can terminate in posterior SC. Nasal axons have to compete with temporal axons in the anterior SC, so they prefer to avoid this competition and terminate only in the posterior SC.

Our results here do not seem easy to explain without an element of competition, and appear to be consistent with a repulsion-competition model. (1) In mouse, the EphA5 ${ }^{\text {laczl }}$ lac $Z$ mutation shifts temporal axons posteriorly and nasal axons anteriorly. According to the competition model, axons from temporal (or central) retina are now able to grow more easily in posterior SC. Nasal axons, therefore, face increased competition 
here, lose their strong preference for this region, and spread out into more anterior regions. (2) In chick, the EphA3 $\Delta$ C construct causes temporal axons to map more posteriorly, which can be explained by the infected RGCs having a lower level of repellent receptor relative to their normal neighbors. The lack of an obvious nasal axon phenotype might be explained by the patchy expression in the chick experiments, so that the competition faced by nasal axons may not be strongly affected, although it is also possible that nasal axons may have had an undershooting phenotype that would be difficult to detect by the methods used here. (3) Axons in the EphA and ephrin-A mutants are not respecified to a specific ectopic position. Instead, there are multiple arborizations, including both normal and abnormal regions. According to the competition model, when topographically specific labels no longer adequately bias the competition, axons are expected to arborize over an abnormally broad region, rather than being retargeted to a specific ectopic location. The lack of an obvious phenotype in the EphA $5^{\text {lac } /+}$ heterozygote could be explained if enough of a gradient remains to adequately bias competition, as suggested for ephrin-A mice which show a phenotype in the ephrin-A $2^{+/-}$; ephrin-A $5^{+/-}$double heterozygote but no obvious phenotype in the single heterozygotes (Feldheim et al., 2000). (4) In the EphA5 and ephrin-A mutants, retinal axons fill the entire SC. Likewise, axons from both nasal and temporal extremes of the retina still form termination zones within the target. These results are difficult to reconcile with mapping models that involve a strict matching of values in the projecting and target field (which would predict that the mutants should have unmatched areas) but can be explained by incorporating competition.

An important feature of axon competition is that it can provide a mechanism to ensure that axons fill the available space. This may be a major advantage biologically, because it can provide a mechanism to ensure that, even if there are variations in the concentrations of the topographically specific labels during development or evolution, the projecting and target areas will still match up. These principles of mapping in the retinotectal system probably apply to other topographic projections and may lend to topographic mapping a robust quality that is increasingly emerging as an important feature in molecular control of many biological systems.

\section{References}

Birgbauer E, Cowan CA, Sretavan DW, Henkemeyer M (2000) Kinase independent function of EphB receptors in retinal axon pathfinding to the optic disc from dorsal but not ventral retina. Development 127:1231-1241.

Brown A, Yates PA, Burrola P, Ortuno D, Vaidya A, Jessell TM, Pfaff SL, O'Leary DDM, Lemke G (2000) Topographic mapping from the retina to the midbrain is controlled by relative but not absolute levels of EphA receptor signaling. Cell 102:77-88.

Bruckner K, Pasquale EB, Klein R (1997) Tyrosine phosphorylation of transmembrane ligands for Eph receptors. Science 275:1640-1643.

Cheng H-J, Nakamoto M, Bergemann AD, Flanagan JG (1995) Complementary gradients in expression and binding of ELF-1 and Mek4 in development of the topographic retinotectal projection map. Cell 82:371-381.

Ciossek T, Lerch MM, Ulrich A (1995) Cloning, characterization, and differential expresssion of MDK2 and MDK5, two novel receptor tyrosine kinases of the eck/eph family. Oncogene 11:2085-2095.

Ciossek T, Monschau B, Kremoser C, Loschinger J, Lang S, Muller BK, Bonhoeffer F, Drescher U (1998) Eph receptor-ligand interactions are necessary for guidance of retinal ganglion cell axons in vitro. Eur J Neurosci 10:1574-1580.

Connor RJ, Menzel P, Pasquale EB (1998) Expression and tyrosine phosphorylation of Eph receptors suggest multiple mechanisms in patterning of the visual system. Dev Biol 193:21-35.

Cutforth T, Moring L, Mendelsohn M, Nemes A, Shah NM, Kim MM, Frisen
J, Axel R (2003) Axonal ephrin-As and odorant receptors: coordinate determination of the olfactory sensory map. Cell 114:311-322.

Davy A, Robbins SM (2000) Ephrin-A5 modulates cell adhesion and morphology in an integrin-dependent manner. EMBO J 19:5396-5405.

Davy A, Gale NW, Murray EW, Klinghoffer RA, Soriano P, Feuerstein C, Robbins SM (1999) Compartmentalized signaling by GPI-anchored ephrin-A5 requires the Fyn tyrosine kinase to regulate cellular adhesion. Genes Dev 13:3125-3135.

DeChiara TM, Vejsada R, Poueymirou WT, Acheson A, Suri C, Conover JC, Friedman B, McClain J, Pan L, Stahl N, Ip NY, Kato A, Yancopoulos GD (1995) Mice lacking the CNTF receptor, unlike mice lacking CNTF, exhibit profound motor neuron deficits at birth. Cell 83:313-322.

Donoghue MJ, Lewis RM, Merlie JP, Sanes JR (1996) The Eph kinase ligand AL-1 is expressed by rostral muscles and inhibits outgrowth from caudal neurons. Mol Cell Neurosci 8:185-198.

Drescher U, Kremoser C, Handwerker C, Löschinger J, Noda M, Bonhoeffer F (1995) In vitro guidance of retinal ganglion cell axons by RAGS, a 25 $\mathrm{kDa}$ tectal protein related to ligands for Eph receptor tyrosine kinases. Cell 82:359-370.

Drescher U, Bonhoeffer F, Muller B (1997) The Eph family in retinal axon guidance. Curr Opin Neurobiol 7:75-80.

Fekete DM, Cepko CL (1993) Retroviral infection coupled with tissue transplantation limits gene transfer in the chicken embryo. Proc Natl Acad Sci USA 90:2350-2354.

Feldheim DA, Vanderhaeghen P, Hansen MJ, Frisen J, Lu Q, Barbacid M, Flanagan JG (1998) Topographic guidance labels in a sensory projection to the forebrain. Neuron 21:1303-1313.

Feldheim DA, Kim YI, Bergemann AD, Frisen J, Barbacid M, Flanagan JG (2000) Genetic analysis of ephrin-A2 and ephrin-A5 shows their requirement in multiple aspects of retinocollicular mapping. Neuron 25:563-574.

Feng GP, Laskowski MB, Feldheim DA, Wang HM, Lewis R, Frisen J, Flanagan JG, Sanes JR (2000) Roles for ephrins in positionally selective synaptogenesis between motor neurons and muscle fibers. Neuron 25:295-306.

Flanagan JG, Vanderhaeghen P (1998) The ephrins and Eph receptors in neural development. Annu Rev Neurosci 21:309-345.

Flenniken AM, Gale NW, Yancopoulos GD, Wilkinson DG (1996) Distinct and overlapping expression patterns of ligands for Eph-related receptor tyrosine kinases during mouse embryogenesis. Dev Biol 179:382-401.

Fraser SE, Hunt RK (1980) Retinotectal specificity: models and experiments in search of a mapping function. Annu Rev Neurosci 3:319-352.

Frisén J, Yates PA, McLaughlin T, Friedman GC, O’Leary DDM, Barbacid M (1998) Ephrin-A5 (AL-1/RAGS) is essential for proper retinal axon guidance and topographic mapping in the mammalian visual system. Neuron 20:235-243.

Godement P, Bonhoeffer F (1989) Cross-species recognition of tectal cues by retinal fibers in vitro. Development 106:313-320.

Goodhill GJ (2000) Dating behavior of the retinal ganglion cell. Neuron 25:501-503.

Goodhill GJ, Richards LJ (1999) Retinotectal maps: molecules, models and misplaced data. Trends Neurosci 22:529-534.

Hattori M, Osterfield M, Flanagan JG (2000) Regulated cleavage of a contact-mediated axon repellent. Science 289:1360-1365.

Henkemeyer M, Orioli D, Henderson JT, Saxton TM, Roder J, Pawson T, Klein R (1996) Nuk controls pathfinding of commissural axons in the mammalian central nervous system. Cell 86:35-46.

Hindges R, McLaughlin T, Genoud N, Henkemeyer M, O’Leary DD (2002) EphB forward signaling controls directional branch extension and arborization required for dorsal-ventral retinotopic mapping. Neuron 35:475-487.

Holland SJ, Gale NW, Mbalamu G, Yancopoulos GD, Henkemeyer M, Pawson T (1996) Bidirectional signalling through the EPH-family receptor Nuk and its transmembrane ligand. Nature 383:722-725.

Holmberg J, Clarke DL, Frisen J (2000) Regulation of repulsion versus adhesion by different splice forms of an Eph receptor. Nature 408:203-206.

Hornberger MR, Dutting D, Ciossek T, Yamada T, Handwerker C, Lang S, Weth F, Huf J, Wessel R, Logan C, Tanaka H, Drescher U (1999) Modulation of EphA receptor function by coexpressed ephrinA ligands on retinal ganglion cell axons. Neuron 22:731-742.

Knoll B, Zarbalis K, Wurst W, Drescher U (2001) A role for the EphA family 
in the topographic targeting of vomeronasal axons. Development 128:895-906.

Lackmann M, Oates AC, Dottori M, Smith FM, Do C, Power M, Kravets L, Boyd AW (1998) Distinct subdomains of the Epha3 receptor mediate ligand binding and receptor dimerization. J Biol Chem 273:20228 -20237.

Lu Q, Sun EE, Klein RS, Flanagan JG (2001) Ephrin-B reverse signaling is mediated by a novel PDZ-RGS protein and selectively inhibits G-protein coupled chemoattraction. Cell 105:69-79.

Maisonpierre PC, Barrezueta NX, Yancopoulos GD (1993) Ehk-1 and Ehk-2: two novel members of the Eph receptor-like tyrosine kinase family with distinctive structures and neuronal expression. Oncogene 8:3277-3288.

Mann F, Ray S, Harris W, Holt C (2002) Topographic mapping in dorsoventral axis of the Xenopus retinotectal system depends on signaling through ephrin-B ligands. Neuron 35:461-473.

Marin O, Blanco MJ, Nieto MA (2001) Differential expression of Eph receptors and ephrins correlates with the formation of topographic projections in primary and secondary visual circuits of the embryonic chick forebrain. Dev Biol 234:289-303.

McLaughlin T, O'Leary DDM (1999) Functional consequences of coincident expression of EphA receptors and ephrin-A ligands. Neuron 22:636-639.

Mellitzer G, Xu Q, Wilkinson DG (1999) Eph receptors and ephrins restrict cell intermingling and communication. Nature 400:77-81.

Mellitzer G, Xu QL, Wilkinson DG (2000) Control of cell behaviour by signalling through Eph receptors and ephrins. Curr Opin Neurobiol 10:400-408.

Menzel P, Valencia F, Godement P, Dodelet VC, Pasquale EB (2001) Ephrin-A6, a new ligand for EphA receptors in the developing visual system. Dev Biol 230:74-88.

Monnier PP, Sierra A, Macchi P, Deitinghoff L, Andersen JS, Mann M, Flad M, Hornberger MR, Stahl B, Bonhoeffer F, Mueller BK (2002) RGM is a repulsive guidance molecule for retinal axons. Nature 419:392-395.

Monschau B, Kremoser C, Ohta K, Tanaka H, Kaneko T, Yamada T, Handwerker C, Hornberger MR, Loschinger J, Pasquale EB, Siever DA, Verderame MF, Muller BK, Bonhoeffer F, Drescher U (1997) Shared and distinct functions of RAGS and ELF-1 in guiding retinal axons. EMBO J 16:1258-1267.

Nakamoto M, Cheng H-J, Friedman GC, McLaughlin T, Hansen MJ, Yoon C, O'Leary DDM, Flanagan JG (1996) Topographically specific effects of ELF-1 on retinal axon guidance in vitro and retinal axon mapping in vivo. Cell 86:755-766.
Nishida K, Flanagan JG, Nakamoto M (2002) Domain-specific olivocerebellar projection regulated by the EphA-ephrin-A interaction. Development 129:5647-5658.

O’Leary DD, Wilkinson DG (1999) Eph receptors and ephrins in neural development. Curr Opin Neurobiol 9:65-73.

Park S, Frisen J, Barbacid M (1997) Aberrant axonal projections in mice lacking EphA8 (Eek) tyrosine protein kinase receptors. EMBO J 16:3106-3114.

Roskies AL, O'Leary DDM (1994) Control of topographic retinal axon branching by membrane-bound molecules. Science 265:799-803.

Simon DK, O'Leary DDM (1992) Responses of retinal axons in vivo and in vitro to position-encoding molecules in the embryonic superior colliculus. Neuron 9:977-989.

Sperry RW (1963) Chemoaffinity in the orderly growth of nerve fiber patterns and connections. Proc Natl Acad Sci USA 50:703-710.

van der Geer P, Hunter T, Lindberg RA (1994) Receptor protein-tyrosine kinases and their signal transduction pathways. Annu Rev Cell Biol 10:251-337.

Walkenhorst J, Dutting D, Handwerker C, Huai J, Tanaka H, Drescher U (2000) The EphA4 receptor tyrosine kinase is necessary for the guidance of nasal retinal ganglion cell axons in vitro. Mol Cell Neurosci 16:365-375.

Walter J, Kern-Veits B, Huf J, Stolze B, Bonhoeffer F (1987a) Recognition of position-specific properties of tectal cell membranes by retinal axons in vitro. Development 101:685-696.

Walter J, Henke-Fahle S, Bonhoeffer F (1987b) Avoidance of posterior tectal membranes by temporal retinal axons. Development 101:909-913.

Wang HU, Anderson DJ (1997) Eph family transmembrane ligands can mediate repulsive guidance of trunk neural crest migration and motor axon outgrowth. Neuron 18:383-396.

Wilkinson DG (2000) Topographic mapping: organising by repulsion and competition? Curr Biol 10:R447-R451.

Xu Q, Alldus G, Holder N, Wilkinson DG (1995) Expression of truncated Sek-1 receptor tyrosine kinase disrupts the segmental restriction of gene expression in the xenopus and zebrafish hindbrain. Development 121:4005-4016.

Zhang JH, Cerretti DP, Yu T, Flanagan JG, Zhou R (1996) Detection of ligands in regions anatomically connected to neurons expressing the Eph receptor Bsk: potential roles in neuron-target interaction. J Neurosci 16: 7182-7192. 